\title{
Pelvis Cancer pT2a TNM Finding v8
}

National Cancer Institute

\section{Source}

National Cancer Institute. Pelvis Cancer pT 2a TNM Finding v8. NCI Thesaurus. Code C136598.

Pelvis cancer with tumor confined to one pelvic segment with extraosseous extension or two segments without extraosseous extension and measuring $8 \mathrm{~cm}$ or less in greatest dimension. (from AJCC 8th Ed.) 